\title{
EFEK PROBIOTIK DAN SELUBIOSE TERHADAP VOLATILE FATTY ACIDS (VFA) DAN NH3 RUMINAL DOMBA GARUT
}

\author{
Atin Supiyani $1^{1^{*}}$ \\ Program Studi Biologi, Fakultas Matematika dan Ilmu Pengetahuan Alam, Universitas Negeri Jakarta \\ *Corresponding Email: Atin_Supiyani@unj.ac.id
}

\begin{abstract}
The composition of feed can improve and optimize the fermentation in sheep rumen. The purpose of this study is to determine the effect of probiotic and cellobiose to rumen fermentation of sheep. Four adult (weight $\pm 13.5 \mathrm{~kg}$ ) rumen fistulae sheep were used. The fed given were King grass (Pennisetum purpureum), rice bran and soybean meal that are protected by formaldehyde $0.3 \%$ as base feed. Fed treatment were probiotics $(0,5 \%$ and $1 \%)$ and cellobiose (1 ppm and $3 \mathrm{ppm}$ ). Parameters measured were $\mathrm{pH}, \mathrm{N}-\mathrm{NH}_{3}$ and VFA concentration of rumen fluid at 0 , 2, 6, 12, and 24 hours after feeding with Completely Randomized Design Factorials $4 \times 5$ and continued with Duncan test $(\alpha=0,05)$. The ruminal $\mathrm{pH}$ range for all treatments between $6.27-6.89$. The maximum $\mathrm{N}-\mathrm{NH}_{3}$ concentration value has been reached at 2 hours after feeding 12.25-18.75 mM. At 0 hours, the total VFA concentration was at an average value of $294.91 \mathrm{mg} \%$ and then increased at 2-6 hours reaching its maximum value in the range $661.97-767.70 \mathrm{mg} \%(\mathrm{p}<0.05)$. The addition of probiotics and cellobiose can optimize rumen fermentation of sheep.
\end{abstract}

Keywords: Probiotic, cellobiose, volatile fatty acids, $\mathrm{NH}_{3}$ ruminal, Garut sheep

\section{PENDAHULUAN}

Produksi daging sangat ditentukan oleh kualitas dan kuantitas pakan yang diberikan, sehingga diperlukan strategi pemberian pakan yang disesuaikan dengan kondisi organ pencernaan agar pemanfaatan zat-zat makanan dapat optimal. Kebutuhan energi diperoleh terutama dari perombakan karbohidrat, lemak dan protein. Dalam sistem pencernaan rumen, senyawa-senyawa organik bahan pakan difermentasi oleh mikroba rumen menghasilkan asam-asam lemak mudah terbang (volatile fatty acids/VFA), karbon dioksida (CO2), hidrogen (H2) dan ammonia (NH3) (Thalib et al., 2010)

Metabolisme zat-zat makanan di dalam rumen dibantu oleh adanya aktivitas biologis dari mikroorganisme rumen. Energi dalam bentuk ATP berasal dari fermentasi karbohidrat menjadi VFA. VFA merupakan salah satu faktor penting untuk pertumbuhan mikroba rumen. Rumen ruminansia terdapat mikroorganisme penghasil enzim selulase. Enzim ini berfungsi memecah selulosa dan hemiselulosa dan menghasilkan glukosa yang akan difermentasikan menjadi VFA, $\mathrm{CO}_{2}$ dan gas metan $\left(\mathrm{CH}_{4}\right)$.

Protein merupakan salah satu nutrisi yang sangat dibutuhkan oleh tubuh. Protein pakan yang dikonsumsi 
oleh ternak, sebagian akan terserap lewat dinding usus, dan sebagian lainnya dikeluarkan melalui feses. Sebagian protein yang terserap tersebut akan dikeluarkan melalui urin dan sebagian lagi akan dideposisikan. Deposisi protein merupakan penimbunan protein yang diperoleh dari protein pakan yang dikonsumsi ternak dikurangi dengan protein yang dikeluarkan melalui feses dan urin (Arifin et al., 2007)

Protein pakan pada ruminansia berasal dari leguminosa dan biji-bijian. Umumnya protein tersebut sedikit yang bebas dari degradasi mikroba rumen. Protein yang tidak terdegradasi dalam rumen dibawa ke usus kemudian dicerna. Hasil akhir degradasi protein di usus berupa asam amino yang akan digunakan oleh tubuh hewan. Bahan pakan sumber protein yang umum diberikan pada ternak adalah bungkil kedelai yang memiliki susunan asam amino yang lengkap. Dilaporkan bahwa bungkil kedelai memiliki nilai biologis yang tidak maksimal jika diberikan pada ternak ruminansia karena memiliki tingkat degradasi rumen yang besar (Puastuti dan Mathius, 2005). Menurut Devant et al. (2000) potensial degradasi bungkil kedelai mencapai $92 \pm 2,7 \%$. Oleh karena itu protein bungkil kedelai perlu dilindungi dari degradasi mikroba dalam rumen. Oleh karena itu pada penelitian ini, protein bungkil kedelai perlu diberi bahan pelindung dari degradasi rumen, yaitu formaldehide.

Probiotik adalah suplemen pakan mikroba hidup yang dapat mempengaruhi hewan tuan rumah secara menguntungkan menelan dengan cara memperbaiki mikroba intestinalnya keseimbangan. Seo et al. (2010) menyatakan bahwa mikroorganisme sush sebagai Lactobacillus, Streptococcus dan Enterococcus umumnya digunakan dalam probiotik untuk ruminansia. Selanjutnya, Saccharomyces cerevisiae dan Aspergilus oryzae adalah dua mikroorganisme langsung yang diberi makan langsung (Direct-fed Microorganism/DFM) yang telah dilengkapi dengan diet diruminansia. Konsentrat yang mengandung L. plantarum dan L. acidophilus lebih efektif menurunkan CH4 produksi dibandingkan probiotik lainnya (Santoso et al., 2014).

Selubiosa adalah induser sintesis selulase yang berfungsi sebagai sumber karbon untuk pertumbuhan sel mikroba yang peranannya dibatasi terhadap sintesis enzim dan bersifat tidak dapat dihidrolisa (Grenet dan Besle, 1991). Dikatakan pula bahwa induser berinteraksi dengan represor menjadi tidak aktif, sehingga menghasilkan biosintesa enzim. Pemecahan serat kasar pakan (selulosa) oleh kerja enzim selulase mikroba rumen. Induser selubiosa diharapkan dapat meningkatkan biosintesa selulase dalam rumen sehingga perombakan karbohidrat dalam fermentasi rumen terutama selulosa dapat berlangsung lebih efisien. Oleh karena itu penelitian ini bertujuan mengetahui efek probiotik dan selubiosa terhadap VFA dan NH3 ruminal domba Garut.

\section{METODE PENELITIAN}

Pada penelitian ini digunakan empat ekor domba Garut jantan berumur 9 bulan dengan bobot badan ratarata 13,5 kg. Sebelum penelitian, dilakukan pembuatan fistula rumen pada bagian abdomen kiri untuk memudahkan pengambilan sampel berupa cairan rumen. Penelitian ini menggunakan pakan terdiri atas hijauan (Rumput Raja), dedak padi dan bungkil kedelai yang dilindungi formaldehid 0,3\% sebagai pakan dasar. Pakan perlakuan berupa probiotik 0,5\% dan 1\% yang dikeluarkan BPT Bogor dan induser selubiosa sebesar 1 ppm dan 3 ppm.

Pada penelitian ini, parameter yang diamati meliputi: $\mathrm{pH}$ rumen, konsentrasi $\mathrm{N}-\mathrm{NH}_{3}$ rumen dan konsentrasi VFA rumen yang terdiri atas asam asetat, asam propionat, asam butirat, asam iso-butirat, asam valerat, dan asam isovalerat. Sampel pengamatan berupa cairan rumen domba Garut dengan varian tingkat waktu pengambilan 0, 2, 6, 12 dan 24 jam setelah pemberian pakan. Pengukuran $\mathrm{pH}$ cairan rumen dengan $\mathrm{pH}$ meter sesaat setelah pengambilan 
sampel. Kadar N-NH3 sebagai indikator fermentabilitas protein ransum ditetapkan dengan metode difusi mikro Conway (Dept. Dairy Sci., 1969). Adapun VFA diukur dengan detilasi uap (Dept. Dairy Sci., 1969).

\section{ANALISA STATISTIK DATA}

Nilai rata-rata dari hasil pengukuran $\mathrm{pH}$ dan konsentrasi $\mathrm{N}_{-} \mathrm{NH}_{3}$ cairan rumen diuji statistic dengan metode Rancangan Acak Lengkap pola Faktorial 4x5. Uji Duncan dilakukan jika diperoleh hasil yang berbeda nyata diantara perlakuan pada taraf $a<0.05$ dengan program SPSS 16.0.

Tabel 1. Komposisi bahan pakan yang digunakan (\% BK)

\begin{tabular}{lcccc}
\hline \multirow{2}{*}{ Jenis Pakan } & \multicolumn{4}{c}{ Perlakuan } \\
\cline { 2 - 5 } & $\mathrm{R} 1$ & $\mathrm{R} 2$ & $\mathrm{R} 3$ & $\mathrm{R} 4$ \\
\hline Rumput Raja & 79,50 & 79,50 & 79,09 & 79,09 \\
Dedak Padi & 11,74 & 11,74 & 11,66 & 11,66 \\
Bungkil kedelai berformaldehid & 8,25 & 8,25 & 8,24 & 8,24 \\
Probiotik & 0,50 & 0,50 & 1,00 & 1,00 \\
Selubiosa (ppm) & 1,00 & 3,00 & 1,00 & 3,00 \\
TOTAL & 100 & 100 & 100 & 100 \\
\hline
\end{tabular}

Tabel 2. Analisa proksimat bahan pakan yang digunakan

\begin{tabular}{lccc}
\hline Jenis Pakan & BK $(\%)$ & PK $(\%)$ & GE $(\mathrm{Kal} / \mathrm{gr})$ \\
\hline K1 dan K2 & 98,95 & 16,11 & 3732 \\
K3 dan K4 & 98,87 & 17,11 & 3620 \\
Rumput Raja & 26,83 & 8,84 & 3859 \\
\hline
\end{tabular}

\section{HASIL DAN PEMBAHASAN}

\section{DERAJAT ASAM (PH) CAIRAN RUMEN}

Kisaran $\mathrm{pH}$ cairan rumen akibat pemberian keempat jenis pakan relatif stabil pada nilai 6,27-6,89. Pada 0 jam rata-rata $\mathrm{pH}$ berada pada nilai 6,57 dan bertahap menurun sampai rata-rata 6,39 pada 6 jam dan meningkat kembali pada 12 jam dengan nilai 6,43 lalu meningkat secara nyata pada 24 jam dengan nilai rata-rata mencapai 6,71 $(\mathrm{P}<0,05)$.

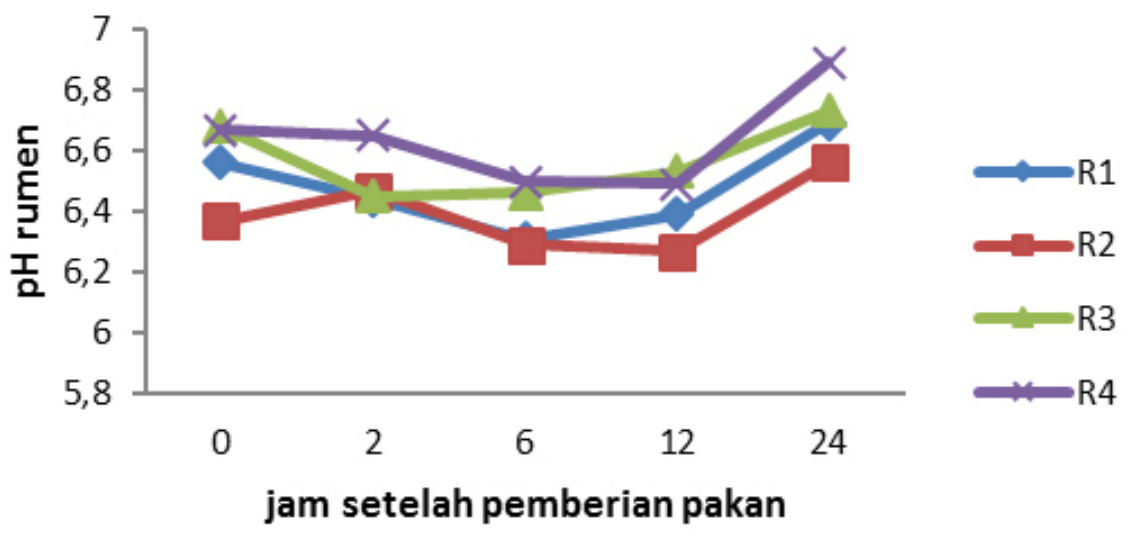

Gambar 1. Nilai rerata $\mathrm{pH}$ cairan rumen domba Garut selama 24 jam waktu pengamatan 
Penelitian Santoso et al. (2014) menghasilkan kisaran pH rumen berada pada kisaran 6,82-6,91. Hasil penelitian ini terjadi penurunan bertahap $\mathrm{pH}$ rumen mencapai nilai terendahnya pada 6 jam setelah pemberian pakan diduga merupakan hasil suatu proses proteolisis pakan oleh mikroba rumen. Hasil penelitian Devant et al. (2000) bahwa perbedaan tingkat degradasi dari bungkil kedelai yang diberi perlakuan dengan dekstrosa dibandingkan dengan bungkil kedelai tanpa perlakuan, tidak mempengaruhi nilai $\mathrm{pH}$ baik pada penggunaan konsentrat tinggi maupun rendah. Sedangkan suatu peningkatan $\mathrm{pH}$ rumen yang nyata $(\mathrm{P}<0.05)$ pada 24 jam diduga merupakan hasil dari pemberian rumput yang kedua kalinya pada sore hari dan proses ruminasi hewan yang dapat mengalirkan saliva ke dalam rumen, dimana saliva tersebut berisi terutama ion bikarbonat yang akan menetralisasi $\mathrm{pH}$ cairan rumen.

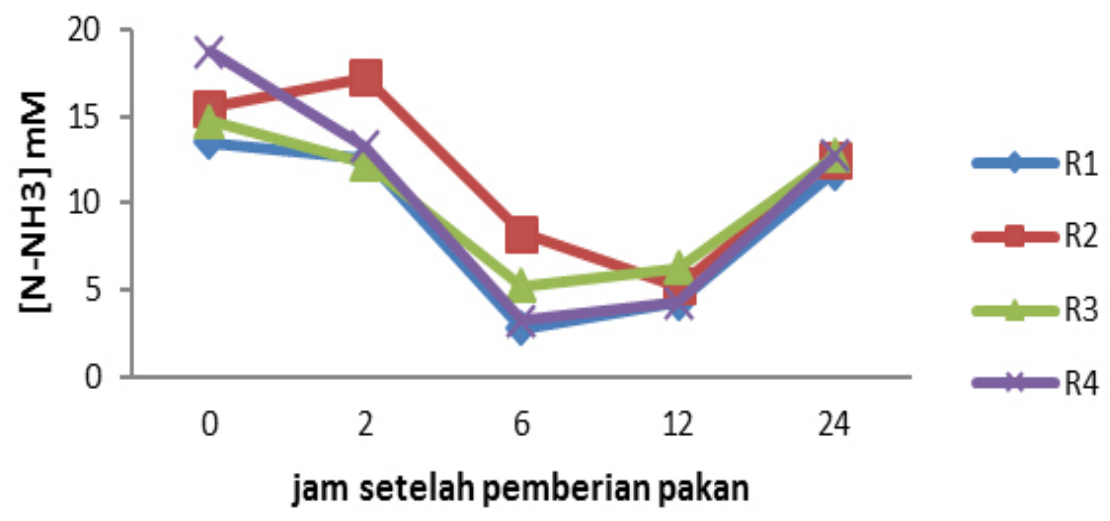

\section{Gambar 2. Nilai rerata konsentrasi N-NH3 cairan rumen domba Garut selama 24 jam waktu pengamatan}

\section{KONSENTRASI N-NH ${ }_{3}$ CAIRAN RUMEN}

Nilai konsentrasi $\mathrm{N}_{-} \mathrm{NH}_{3}$ maksimum sudah dicapai pada saat 2 jam setelah pemberian pakan yaitu pada kisaran 12,25-18,75 mM, yang berarti sudah tersedia $\mathrm{N}$ dari hasil degradasi makanan yang dapat digunakan untuk biosintesa sel mikroba rumen. Menurut Hungate (1966) bahwa produksi $\mathrm{N}_{-} \mathrm{NH}_{3}$ mencapai nilai maksimum pada 2-4 jam setelah pemberian pakan, tergantung pada sumber protein yang digunakan dan tingkat degradasi protein pakan dalam rumen.

Pada domba Garut yang telah dilaporkan oleh Thalib et al. (2010) nilai NH3 rumen domba Garut yang diberi pakan hijauan berserat tinggi berada pada kisaran 162-184 mg/L atau setara dengan 10,7 mM. Sementara penelitian Fauziah (1999) memperoleh konsentrasi $\mathrm{N}_{-} \mathrm{NH}_{3}$ rumen sebesar 2,4-7,4 mM pada domba yang hanya diberi rumput lapangan dan sebesar 2,7-15,23 mM pada domba yang diberi tambahan 0,5 kg dedak padi. Penambahan konsentrat dapat meningkatkan konsentrasi $\mathrm{N}-\mathrm{NH}_{3}$ rumen karena merupakan sumber protein yang mudah dicerna mikroba rumen. Konsentrasi amonia di dalam rumen merupakan salah satu faktor yang menentukan efisiensi sintesa protein pakan yang pada akhirnya dapat mempengaruhi hasil fermentasi bahan organik pakan. Diketahui pula, produksi $\mathrm{N}-\mathrm{NH}_{3}$ mencapai nilai maksimum pada 2-4 jam setelah pemberian pakan, tergantung pada sumber protein yang digunakan serta tingkat degradasi protein pakan dalam rumen.

Hasil analisa statistik menunjukkan bahwa tidak ada pengaruh nyata akibat pemberian keempat jenis pakan terhadap konsentrasi $\mathrm{N}-\mathrm{NH}_{3}$ cairan rumen, tetapi terdapat penurunan yang nyata $(\mathrm{P}<0.05)$ pada 6-12 jam setelah pemberian pakan. Penurunan ini diduga akibat menurunnya degradasi protein pakan dan penggunaan $\mathrm{N}$ secara maksimal untuk biosintesa sel mikroba rumen. 


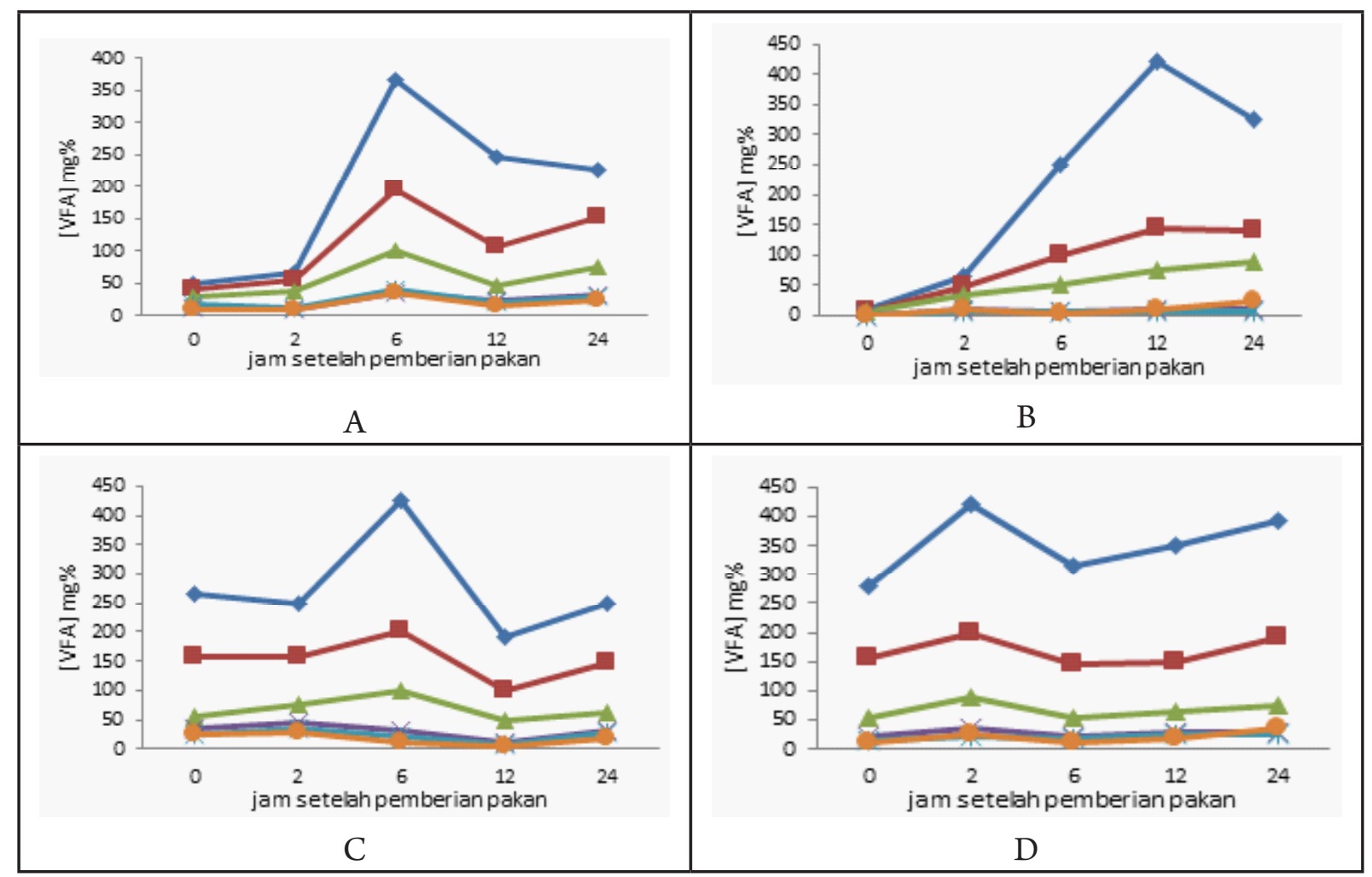

Gambar 2. Nilai rerata konsentrasi N-NH3 cairan rumen domba Garut selama 24 jam waktu pengamatan KONSENTRASI VFA CAIRAN RUMEN

Konsentrasi VFA total pada 0 jam berada pada nilai rata-rata 294,91 mg\% lalu meningkat pada 2-6 jam mencapai nilai maksimumnya pada kisaran $661,97-767,7 \mathrm{mg} \%$. Peningkatan ini diduga merupakan hasil dari aktivitas selulolitik mikroba rumen yang meningkat dan intensif pada 2-6 jam setelah pemberian pakan. Fauziah (1999) melaporkan bahwa pada domba Garut yang diberi rumput dan ditambah 0,5 kg dedak menghasilkan konsentrasi VFA total sebesar 200-380 mg\%.

Dari Gambar 3 dapat diketahui bahwa pola fermentasi VFA yang dihasilkan akibat pemberian R1 meningkat secara bertahap sesuai dengan waktu setelah pemberian pakan mencapai nilai maksimalnya pada 6 jam lalu menurun kembali pada 12-24 jam. Akibat pemberian R2 terlihat bahwa nilai maksimal dari konsentrasi VFA rumen dicapai setelah 12 jam, dimana terlihat adanya peningkatan yang sangat besar terhadap asam asetat. Hal ini dapat merupakan indikasi bahwa telah terjadi aktivitas selulolitik yang sangat intensif dan dalam jumlah yang besar dibandingkan dengan R1, diduga akibat mikroba rumen lebih banyak mendapatkan energi untuk dapat mensintesa enzim selulase yang dapat memecah selulosa. Level pemberian selubiosa sebesar 3 ppm dapat menginduksi sintesa enzim selulase dari mikroba rumen.

Pada gambar di atas terlihat bahwa pola fermentasi VFA akibat pemberian R3 dan R4 cenderung berbeda dengan R1dan R2. Perbedaan pertama yaitu pada 0 jam terdapat konsentrasi VFA yang cukup besar dan cenderung tidak berubah pada 2 jam lalu meningkat mencapai titik maksimalnya pada 6 jam, dan kedua adalah terjadinya peningkatan kembali konsentrasi VFA pada 24 jam. Hal ini diduga merupakan suatu hasil dari proses remastikasi hewan pada malam harinya. Dengan level pemberian 3 ppm selubiosa pada R4 terlihat bahwa telah dicapai nilai maksimum pada 2 jam setelah pemberian pakan, lalu menurun pada 6 jam dan meningkat kembali pada 12-24 jam setelah pemberian pakan. 
Fauziah (1999) menyatakan bahwa pada domba Garut yang diberi rumput menghasilkan rasio C2:C3:C4 sebesar 61-64 : 23-27:12-13 pada domba yang diberi rumput dan sebesar 57-60:18-23:20-22 pada domba yang diberi tambahan $0,5 \mathrm{~kg}$ dedak. Juga dihasilkan pola fermentasi VFA yang sama dengan pola fermentasi R3 dan R4 pada penelitian ini. Dari keempat jenis pakan diketaui bahwa level $1 \%$ probiotik menunjukkan pola fermentasi pada R3 dan R4 memiliki konsentrasi VFA pada 0 jam yang lebih tinggi dibandingkan R1 dan R2, sedangkan level 3 ppm selubiosa menghasilkan peningkatan jumlah asam asetat yang cukup tinggi pada pola fermentasi R2 dan R4 dibandingkan dengan level pemberian 1 ppm selubiosa pada R1 dan R3.

Penambahan probiotik dan selubiosa pada penelitian ini telah menghasilkan peningkatan jumlah asam propionat yang cukup besar. Hal ini dapat disebabkan oleh (1) peningkatan jumlah karbohidrat mudah larut dari pakan yang menyediakan energi cukup besar bagi mikroba rumen untuk menjalankan aktivitas biologisnya; (2) terjadi peningkatan jumlah mikroba selulolitik sehingga pencernaan selulosa dalam bentuk asam asetat terlihat jelas; (3) peningkatan kadar asam propionat dapat mensuplai lebih banyak energi berupa glukosa bagi hewan untuk kebutuhan esensial jaringan tubuhnya

\section{SIMPULAN DAN SARAN}

Pakan yang mengandung komposisi R2 dapat menghasilkan pola fermentasi rumen yang lebih baik dibandingkan R1, R3 dan R4. Perlu dilakukan penelitian lanjutan dengan kombinasi probiotik dan selubiosa yang lebih bervariasi baik secara kualitas maupun kuantitas.

\section{TERIMA KASIH}

Terima kasih disampaikan kepada Prof. Dewi Apri Astuti (IPB) dan Ir. F. Dwiranti, M.Si. (Universitas Cendrawasih) yang telah mensponsori penelitian ini.

\section{DAFTAR PUSTAKA}

Arifin M., A. Isminursiti dan E. Rianto. 2007. Deposisi protein pada domba ekor tipis jantan yang diberi pakan hijauan dan konsentrat dengan metode penyajian berbeda. Seminar Nasional Teknologi Peternakan dan Veteriner. Prosiding halaman 367-373.

Department of Dairy Science. 1969. General Laboratory Procedure. University of Wisconsin, Madison

Devant, M. A. Ferret, J.Gasa, S. Calsamiglia dan R. Casals. 2000. Effects of protein concentration and degradability on performance, ruminal fermentation and nitrogen metabolisme in rapidly growing Heifers Fed-concentrate Diets from 100 to $230 \mathrm{Kg}$ Body Weight. J.Anim.Sci. 78:1667-1676

Fauziah. 1999. Gambaran Pola Fermentasi Rumen selama 8 jam Pasca Makan Pagi pada Domba Garut yang Diberi Pakan dengan dan tanpa Konsentrat [Skripsi]. Bogor (ID): Institut Pertanian Bogor.

Grenet, E. dan J.M. Besle. 1991. Microbes and Fibre Degradation. Dalam: Rumen Microbial Metabolism and Ruminant Digestion. J.P. Jouany ed. INRA edition, Paris, hal. 107-125.

Hungate, R.E. 1966. The Rumen dan Its Microbes. Academic Press, hal. 533.

Puastuti W., dan I.W. Mathius. 2005. Pengaruh Substitusi bungkil kedelai terproteksi getah pisang sebagai sumber protein tahan degradasi terhadap fermentasi rumen. Seminar Nasional Teknologi Peternakan dan 
Veteriner. Prosiding. Halaman 405-409.

Santoso B, B. Tj. Hariadi dan H. Abubakar. 2014. The Effect of Concentrate Containing Probiotics on Fermentation Characteristics, Methanogenesis and In Vitro Nutrient Digestility. J. Indonesian Trop. Anim. Agric. $39(4): 210-216$

Seo, J. K., S. W. Kim, M. H. Kim, S. D. Upadhaya, D. K. Kam and J. K. Ha. 2010. Direct-fed microbials for ruminant animals. Asian-Aust. J. Anim. Sci. 23:1657-1667

Thalib A, Y. Widiawati dan B. Haryanto. 2010. Penggunaan Complete Rumen Modifier (CRM) pada Ternak Domba yang Diberi Hijauan Pakan Berserat Tinggi. JITV, Volume 15 (2): 97-104 